\title{
REGULASI PENATAAN PASAR MODERN DAN REVITALISASI PASAR TRADISIONAL DI KOTA BLITAR
}

\author{
Wydha Mustika Maharani, \\ Fakultas Ilmu Sosial dan Ilmu Politik, Universitas Islam Balitar Blitar \\ Email : wydhamustika7@gmail.com
}

\begin{abstract}
The development of a modern market and shopping centers more quickly in Indonesia could no longer avoid. The development of this phenomenon indirectly can threaten the traditional markets. To anticipate, envy and social unrest then required regulation which control modern market and required an apparent attempt to maintain and develop traditional markets in the revitalization of traditional markets. This research aims to: (1) knowledge and describe regulations modern markets that already exist, but in its implementation regulations modern markets are not aligned with the existing especially in relation to the distance between modern markets and traditional markets. (2) knowledge and describe revitalization program traditional markets to protect traditional markets in order to compete with modern market. This research adopted qualitative descriptive approaches. The research results show that the dualistic economic between a modern market with traditional markets made difficult the collaboration between them.
\end{abstract}

Key words: Public Policy, Regulations The Revitalization Of, Traditional Markets, A Modern Market

\section{Pendahuluan}

Di dalam penyelenggaraan negara sangat dibutuhkan regulasi untuk mengatur segala macam kegiatan agar implementasinya berjalan dengan baik. Regulasi tersebut digunakan sebagai instrument untuk merealisasikan setiap kebijakan negara, maka dari itu regulasi harus dibentuk dengan cara yang benar sehingga mampu menghasilkan regulasi yang baik dan mampu mendorong terselenggaranya dinamika sosial yang tertib serta mampu mendorong kinerja penyelenggaraan negara (Kementrian PPN/Bappenas 2015: 3).

Sampai saat ini, regulasi di bidang pembangunan ekonomi masih menjadi salah satu sasaran utama yang terus diupayakan oleh pemerintah dalam mencapai kemakmuran rakyat. Pembangunan ekonomi tidak hanya berkaitan dengan pertumbuhan ekonomi semata, namun juga terjadinya perubahan di berbagai 
aspek kegiatan ekonomi seperti peningkatan infrastruktur, peningkatan pendapatan dan kemakmuran masyarakat (Sukirno, 2010: 10).

Fenomena berkembangnya pasar modern dan pusat perbelanjaan di Indonesia sudah tidak dapat dihindarkan lagi. Berbagai jenis pasar modern banyak ditemui di ruas-ruas jalan, baik di kompleks perumahan, perkotaan dan juga perdesaan. Adanya pasar modern (hypermarket, supermarket, dan minimarket) berdampak mematikan pasar tradisioanal. Maraknya minimarket yang ada di tengah-tengah pusaran pasar tradisional membuat banyak pedagang tradisional khawatir dan mengeluh karena penjualannya semakin menurun.

Regulasi mengenai penataan pasar modern dan pasar tradisional sudah lama dibuat termuat dalam Undang-undang No. 7 Tahun 20014; Peraturan Presiden Nomor 112 Tahun 2007; Peraturan Menteri Perdagangan No. 70 Tahun 2013. Namun, kebijakan Pemerintah Daerah yang tetap menjadi kunci dilaksanakannya regulasi tersebut. Setiap Pemerintah Daerah harus mengakomodasi dan mengadopsi peraturan mengenai penataan pasar modern dan pentingnya revitalisasi pasar tradisional dengan menerbitkan Peraturan Daerah sebagai acuan peraturan mengenai penataan pasar modern dimasing-masing daerah.

Pasar tradisional yang sebelumnya dikenal dengan tempatnya yang kumuh, kotor, berbau, jalannya becek, dan terlihat kurang menarik kerap menjadi kendala untuk dapat bersaing dengan pasar modern. Sebagai contoh pasar yang berada di Provinsi Jawa Timur tepatnya di Kota Blitar mengalami berbagai macam persoalan, diantaranya: Pasar Legi dan Pasar Templek nampak kotor, kumuh, dan jalannya becek; Pasar Paing dan Pasar Wage sudah dibangun namun pasar terlihat sepi penjual dan pembeli. Masyarakat Kota Blitar nampaknya lebih tertarik berbelanja di pasar modern seperti Alfamart dan Indomart karena pelayanannya baik selain itu juga menyediakan berbagai macam kebutuhan serta mudah ditemui. Di Kota Blitar sendiri, sedikitnya terdapat 30 minimarket yang beroperasi tanpa mengantongi izin usaha toko modern (IUTM). Sejauh ini, Pemerintah Kota Blitar belum memiliki kekuatan untuk melakukan penertiban (www. news.okezone.com diakses pada 10 April 2019). 
Dari persoalan tersebut, maka peneliti mencoba mengkaji ulang regulasi yang mengatur keberadaan pasar modern agar tidak mengancam keberlangsungan pasar tradisional dan juga mencoba mencari solusi agar pasar tradisional mampu bersaing dengan pasar modern.

\section{Metode Penelitian}

Penelitian ini menggunakan pendekatan kualitatif. Sejalan dengan tujuan tersebut, penelitian ini menggunakan pendekatan kualitatif deskriptif bertujuan agar dapat memahami masalah dalam perspektif makna berdasarkan pengalaman setiap individu masing-masing informan (Denzin \& Lincoln, 2005: 1-19; Merriam, 2002: 1-6) sebagai representasi pihak-pihak yang terlibat dalam penataan pasar modern dan revitalisasi pasar tradisional di Kota Blitar. Dengan menggunakan berbagai jenis data kualitatif terkait pikiran dan keyakinan para informan yang diperoleh melalui wawancara individu maupun diskusi kelompok yang dilengkapi data lain yang relevan seperti catatan buku harian, mengutip dari dokumen yang diterbitkan, dan data non-tekstual dari gambar, audio, dan video rekaman dan sumber lainnya (Patton, 2002: 1-3; Srivastava \& Thomson, 2009).

Lokasi penelitian ini adalah di Kota Blitar. Pemilihan lokasi tersebut dilakukan atas berbagai pertimbangan diantaranya adalah: (1) terdapat ketimpangan yang terjadi antara pasar tradisional dan pasar modern, yang mana pasar tradional tidak mampu bersaing dengan pasar modern; (2) penelitian tentang regulasi pasar modern dan revitalisasi pasar tradisonal menurut peneliti belum memadai sehingga perlu dilakukannya penelitian lebih lanjut; (3) terdapat data yang mendukung untuk dilakukannya penelitian ini.

\section{Pembahasan}

\section{Regulasi Penataan Pasar Modern di Kota Blitar}

Dinas Perindustrian dan Perdagangan Kota Blitar mengkhawatirkan toko swalayan dan minimarket semakin bertambah banyak jumlahnya. Regulasi yang mengatur keberadaan pasar modern memang sudah ada yaitu Peraturan Daerah Kota Blitar No. 1 Tahun 2018 tentang Penyelenggaraan Pasar Rakyat, Pusat 
Perbelanjaan dan Toko Swalayan. Namun, Peraturan Daerah tersebut belum bisa dilaksanakan karena disebabkan oleh belum adanya Peraturan Walikota yang menjelaskan secara teknis penataan pasar modern. Sebagai contoh, daya tampung kawasan hanya cukup untuk 10 toko swalayan, sedangkan yang mengajukan izin ada sebanyak 30 orang (www.surabaya.tribunnews.com diakses pada 10 April 2019) Perlu adanya regulasi yang secara nyata dan jelas mengatur pasar modern agar tidak mengancam keberadaan pasar tradisional.

Di dalam Peraturan daerah No. 1 Tahun 2018 disebutkan bahwa pasar modern setidaknya harus berada pada jarak minimal 500 meter dari pasar tradisional. Hal tersebut harus diperhatikan agar tidak mematikan pasar tradisional. Sebab jika tidak diatur maka pelaku usaha kecil akan kalah dengan pelaku usaha besar. Dengan hadirnya pasar modern Pemerintah Daerah dapat memanfaatkan peluang tersebut dengan cara mengoptimalkan distribusi produk unggulan daerah. Sebagai contoh, ketika suatu pasar modern hendak masuk ke daerah, Pemerintah Daerah harus memberi syarat-syarat yang memaksa untuk bermitra dengan produsen lokal. Bisa saja dengan syarat produk lokal harus dijual sekian persen. Selain itu juga, produk yang dijual di pasar modern harus berbeda dengan yang dijual di pasar tradisional. Misalnya saja pasar modern tidak boleh menjual buah-buahan dan sayuran.

Pemberdayaan sumberdaya manusia harus diprioritaskan karena pasar modern dapat menyerap banyak tenaga kerja. Di dalam Peraturan Daerah Kota Blitar No. 1 Tahun 2018 sudah termuat bahwa merekrut sekurang-kurangnya 70\% tenaga kerja daerah. Namun, hal tersebut perlu pemantauan lebih lanjut demi menertibkan aturan pemerintah.

\section{Revitalisasi Pasar Tradisional di Kota Blitar}

Pasar tradisional memiliki banyak hambatan agar mampu sejajar dan tumbuh bersama pasar modern. Hambatan tersebut di antaranya adalah belum mempunyai tempat dagang yang nyaman; masih menjunjung tinggi nilai sosial budaya saat berbelanja seperti adanya tawar menawar antara pedagang dan pembeli; branding toko; budaya bergosip di pasar; masalah margin harga yang disebabkan oleh 
pedagang tidak bisa langsung membeli barang dari pabrik namun harus melewati beberapa seles sehingga barang yang dijual toko tradisional cenderung lebih mahal dari toko modern akibat cost logistic. Dari hambatan tersebut nampaknya Pemerintah perlu mencari solusi agar pasar tradisional mampu bersaing dengan pasar modern.

Pemerintah daerah telah melakukan beberapa upaya pembangunan perekonomian lokal dan salah satunya dengan melaksanakan program revitalisasi pasar. Namun, berdasarkan sejumlah realita yang ada menunjukkan belum optimalnya pelaksanaan revitalisasi pasar. Pada dasarnya upaya perbaikan pasar tradisional bukan hanya menitikberatkan pada unsur fisik semata, namun lebih dari pada itu perbaikan aspek manajemen menjadi sebuah keharusan yang perlu untuk dilakukan. Perbaikan manajemen pengelolaan pasar akan menjadikan pasar tradisional lebih terarah, dalam hal ini berkaitan dengan keberadaan pedagang, tata cara, maupun standar operasional prosedur pelayanan pasar. Oleh karenanya perbaikan unsur non-fisik juga menjadi elemen penting bagi terwujudnya pembangunan pasar yang berkelanjutan.

Upaya revitalisasi menjadi kesempatan terbaik yang seharusnya dapat dilaksanakan seoptimal mungkin oleh pemerintah daerah dalam memperbaiki kondisi pasar tradisional. Profesionalitas pengelola pasar menjadi bagian yang turut berpengaruh terhadap penyelenggaraan program revitalisasi dalam mecapai sasaran yang diinginkan. Sebagai contoh dibentuknya lembaga RT atau RW di tiap wilayah pasar sehingga penduduk pasar memiliki hak dan kewajiban untuk melakukan hal yang baik seperti menjaga kebersihan (www.surabaya.bisnis.com diakses pada 9 April 2019).

Pemerintah Provinsi Jawa Timur mendorong 11 pasar tradisional untuk menerima program revitalisasi pasar berstandar nasional (SNI). Kepala Bidang Perdagangan Dalam Negeri Dinas Perindustrian dan perdagangan Jawa Timur mengungkapkan Pemerintah Pusat mencanankan program revitalisasi pasar tradisional. Terdapat 1.030 pasar yang akan didanai dan Provinsi Jawa Timur mendapat jatah 11 pasar. Saat ini masih terdapat 2 pasar tradisional yang sudah berstandar nasional yaitu pasar Oro-Oro Dowo Malang dan Pasar Kapongan 
Situbondo. Syarat untuk mendapatkan SNI yaitu legalitas tanah harus jelas, bentuk bangunan harus layak, lapak harus bagus dan bersih, saluran air lancar, tersedianya tempat laktasi, serta tersediannya kamera CCTV. (www.surabaya.bisnis.com diakses pada 9 April 2019)

Sebanyak 11 pasar tradisional di Jawa timur mendapat kucuran anggaran revitalisasi dari pemerintah pusat di tahun 2019. Besarnya Rp. 44 miliar atau masing-masing pasar mendapat jatah Rp. 4 miliar. 11 pasar rakyat yang akan direvitalisasi tahun 2019 diantaranya adalah Pasar Sayur Bantur Malang; Pasar Guluk-Guluk Sumenep; Pasar Rojokoyo Banjarejo Bojonegoro; Pasar Warung Dowo Pasuruan; Pasar Kenduruan Tuban; Pasar Klojen Lumajang; Pasar Prapanca Mojokerto; Pasar Karangan Trenggalek; Pasar Kerep Nganjuk; Pasar Wlingi Blitar; dan Pasar Paiton Probolinggo. (www.wartatransparansi.com diakses pada 9 April 2019).

Terlepas dari program revitalisasi pasar tradisional Provinsi Jawa Timur, Pemerintah Kota Blitar juga mencanankan program serupa. Di Kota Blitar terdapat 6 pasar tradisional, diantaranya:

Tabel 1

Daftar Pasar Tradisional

\begin{tabular}{|c|l|l|}
\hline No. & \multicolumn{1}{|c|}{ Nama Pasar } & \multicolumn{1}{|c|}{ Alamat } \\
\hline 1. & Pasar Legi & Jl. Raya Mawar No. 12 \\
\hline 2. & Pasar Pon & Jl. Raden Ajeng Kartini \\
\hline 3. & Pasar Pahing & Jl. Mahakam No. 102 \\
\hline 4. & Pasar Wage & Jl. Mastrip \\
\hline 5. & Pasar Templek & Jl. Kaca Piring \\
\hline 6. & $\begin{array}{l}\text { Pasar Hewan Terpadu } \\
\text { Dimoro }\end{array}$ & Jl. Batanghari \\
\hline
\end{tabular}

Sumber: Data diolah

Kepala Dinas Perindustrian dan Perdagangan Kota Blitar pada tahun 2019 Pemerintah Kota Blitar mulai menyiapkan pembangunan tiga pasar tradisional. Ketiga pasar tersebut adalah Pasar Legi, Pasar Hewan Terpadu Dimoro, dan Pasar Sayur yang akan dibangun di selatan Terminal Patria. Anggaran yang dikeluarkan APBD Kota Blitar untuk revitalisasi pasar tradisional sebesar Rp. 50 miliar. Sedangkan untuk pembangunan Pasar Sayur, Pemerintah Kota Blitar 
mendapatkan bantuan Pemerintah Pusat sebesar Rp. 6 miliar (www.suryamalang.tribunnews.com diakses pada 9 April 2019)

Dana yang digunakan untuk revitalisasi rata-rata berjumlah tidak sedikit, untuk itu perlu dilakukan beberapa kajian untuk memformulasikan program revitalisasi pasar tradisional agar program tersebut berjalan baik dan pada akhirnya pasar tradisional mampu bersaing dengan pasar modern. Formulasi kebijakan atau regulasi tersebut meliputi analisa sosial ekonomi, analisa sosio demografi, analisa potensi lokal dengan melibatkan semua elemen yang berkepentingan di dalamnya baik pihak pemerintah daerah, swasta melalui program CSR dan masyarakat.

Masyarakat yang dimaksud di sini bukan hanya masyarakat sebagai konsumen tetapi masyarakat yang bertindak dan berperan sebagai pelaku ekonomi yaitu para pedagang di pasar. Pasar tersebut biasanya dinaungi dalam sebuah paguyupan pedagang pasar. Hal ini penting karena mereka yang terlibat langsung dan merupakan pelaku ekonomi di pasar tradisional. Untuk itu penting sekali melakukan focus grup discussion ataupun sounding antara pemerintah, swasta dan masyarakat. Dengan metode FGD dan sounding ini diharapkan mampu menyerap aspirasi semua pihak agar nantinya dapat merumuskan kebijakan atau regulasi revitalisasi pasar secara efektif dan efisien. Kebijakan tersebut mampu menjadi solusi dari banyaknya masalah dan hambatan dalam upaya revitalisasi pasar tradisional sebagai wujud peningkatan perekonomian masyarakat di Kota Blitar.

\section{Kesimpulan dan Saran}

1) Upaya Pemerintah Pusat dan Pemerintah Daerah dalam merevitalisasi pasar tradisional nampaknya sudah mulai dirasakan oleh sebagian masyarakat. Untuk mendukung program revitalisasi pasar tradisional maka diperlukan regulasi penataan pasar modern. Dengan tujuan agar pasar tradisional mampu bersaing dengan pasar modern. Selain itu, perlu adanya program kemitraan antara pasar modern dengan pasar tradisional (pedagang kaki lima dan UKM).

2) Agar kebijakan Pemerintah Daerah efektif serta menjadi payung hukum yang kuat maka kebijakan perlindungan terhadap pasar tradisional harus disosialisasikan 
kepada legislatif sehingga mendapatkan pengawasan dari legislatif. Selain itu, untuk meningkatkan pemahaman kepada legislatif perlu dilakukannya studi banding dengan pemerintah daerah yang sukses membangun hubungan kerja sama antara pelaku usaha kecil dan pasar modern. Bersama-sama menciptakan iklim yang kondusif dan tumbuh bersama dengan pelayanan yang baik dan manajemen yang rapi sehingga konsumen menjadi diuntungkan.

\section{Daftar Pustaka}

Denzin, N.K \& Lincoln, Y.L., eds. 2005. Handbook of Qualitatice Research, $3^{\text {rd }}$ Ed., California: Dage Publications Inc.

Kementrian PPN/Bappenas, 2015, Strategi Nasional Reformasi Regulasi, Mewujudkan Regulasi yang Sederhana dan Tertib, Jakarta: Kementrian PPN/Bappenas

Merriam, S. B., et. Al., 2002. Qualitative Research in Practice: Examples for Discussion and analysis. San Francisco: Jossey-Bass Publishers.

Undang-undang No. 7 Tahun 20014 tentang Perdagangan

Peraturan Presiden Nomor 112 Tahun 2007 tentang Penataan dan Pembinaan Pasar Tradisional, Pusat Perbelanjaan dan Toko Modern

Peraturan Menteri Perdagangan No. 70 Tahun 2013 tentang Pedoman Penataan pasar Tradisional, Pusat Perbelanjaan dan Toko Modern.

Peraturan Daerah Kota Blitar No. 1 Tahun 2018 tentang Penyelenggaraan Pasar Rakyat, Pusat Perbelanjaan dan Toko Swalayan

www.news.okezone.com

www.kemendag.go.id

www.presidenri.go.id

www.surabaya.bisnis.com

www.surabaya.tribunnews.com

www.suryamalang.tribunnews.com

www.wartatransparansi.com 